\section{Re: Skråblikk fra et sykehusmottak}

Dette var morsomt skrevet, men om jeg må sette fingeren på noe, blir noen av overdrivelsene kanskje litt ødeleggende for det underliggende budskapet. Dessverre, overdrivelser eller ei, så er det mye sannhet i det Lilleås skriver (1). Selv med min minimale erfaring fra arbeid i det norske helsevesen, kjenner jeg meg igjen i det meste. Papirmøllen går på regnskogen løs. Beskrivelsen av at man ender opp med å gjøre en jobb som er akkurat god nok, og gjør man mer, oppnår man ingen ting annet enn mer arbeid, er treffende.

Som turnuslege kan jeg jo tilføye at man til stadighet føler seg mer som en byrde for ledelsen enn en potensiell ressurs. Det blir de mer erfarne legers oppgave å rydde opp i rotet vi lager i akuttmottaket. Vi skal helst holde oss unna de sykeste, da vi ikke er flinke nok. Ironien topper seg når man bruker mesteparten av introduksjonsdagene ved oppstart til å forsøke å lære seg den elektroniske pasientjournalen, og man inviteres på kurs for å bli bedre til å kode. Jeg krummer nakken, epikrisene venter - husk E86!

\section{Marius Erik Grøvlen}

gmariuse@gmail.com

Marius Erik Grøvlen (f. 1987) er turnuslege ved Sykehuset Telemark. Ingen oppgitte interessekonflikter.

Litteratur

1. Lilleås E. Skråblikk fra et sykehusmottak. Tidsskr Nor Legeforen 2015; 135 $266-7$.

\section{Re: Skråblikk fra et sykehusmottak}

Dette er det beste jeg har lest på mange år (1)! Og en av grunnene til at jeg valgte å bli patolog. Etter min mening er New Public Management det verste som har hendt pasienter og helsepersonell noensinne.

\section{Cecilie Fiva}

fiva-lan@online.no

Cecilie Fiva (f. 1972) er overlege ved Nordlandssykehuset Bodø Ingen oppgitte interessekonflikter.

\section{Litteratur}

1. Lilleås E. Skråblikk fra et sykehusmottak. Tidsskr Nor Legeforen 2015; 135 $266-7$.

\section{Re: Hørselstap hos barn i Østfold 2000-09}

I Tidsskriftet nr. 2/2015 har Siri Nelson og medarbeidere en meget lesverdig artikkel om medfødt hørselstap hos barn i Østfold 2000-09 (1). Tidsskriftet har også fulgt opp med en kommenterende lederartikkel av Hans H. Elverland (2). Slik det også fremgår av arbeidet, er den alt overveiende andel av medfødt hørselstap genetisk betinget. Men en liten andel medfødt hørselstap skyldes kongenitale infeksjoner. Den viktigste ikke genetisk betingede årsak til medfødt hørselstap er cytomegalovirusinfeksjon (CMV) (3). Denne mulighet er ikke undersøkt, ei heller diskutert i artikkelen.

Basert på undersøkelser i Sverige og Storbritannia kan vi anta at ca 5 av 1000 nyfødte har en kongenital CMV-infeksjon (3). Av disse vil 10-20\% få nevrologisk sekvele, oftest i form av sensorisk hørselstap. Dette er små tall, men vi mener påvisning av medfødt CMV infeksjon som årsak til hørselsnedsettelse er viktig fordi tidlig innsettende behandling med ganciclovir/valganciclovir kan redusere skadens omfang (4). Hvis CMV kan påvises i urin eller spytt ved PCR i prøve tatt innen tre uker etter fødsel, så betyr det at infeksjonen fant sted før fødsel. Noen ganger kan det gå måneder eller år før CMV-betinget hørselsskade blir manifest (3). Diagnosen medfødt CMV infeksjon kan da stilles ved å påvise CMV-DNA ved PCR i blod tatt ved nyfødtscreening og lagret på filterpapir ved Pediatrisk forskningsinstitutt, Oslo universitetssykehus. Vårt laboratorium, som har nasjonal referansefunksjon for CMV, har etablert en metode for påvisning av CMV i blodprøver lagret på filterpapir. Imidlertid angis sensitiviteten til bare $60-70 \%$, men spesifisiteten er bortimot $100 \%$.

Vi mener det nå bør diskuteres om det er regningssvarende å screene nyfødte for CMV-infeksjon når hørselstest utført på barselavdelingen indikerer nedsatt hørsel.

\section{Halvor Rollag}

Halvor.rollag@medisin.uio.no

Ellen Holter

Fredrik Müller

Halvor Rollag (f. 1945) er professor/overlege ved Avdeling for mikrobiologi, Oslo universitetssykehus, Rikshospitalet.

Ingen oppgitte interessekonflikter.

Ellen Holter (f.1948) er medisinsk ansvarlig overlege for virologisk diagnostikk ved Avdeling for mikrobiologi, Oslo universitetssykehus, Rikshospitalet.

Ingen oppgitte interessekonflikter.

Fredrik Müller (f.1954) er professor/overlege og seksjonsleder for Utviklingsseksjonen, Avdeling for Mikrobiologi, Oslo Universitetssykehus. Ingen oppgitte interessekonflikter.

\section{Litteratur}

1. Nelson S, Andersen R, Anderssen SH. Hørselstap hos barn i Østfold 2000-09. Tidsskr Nor Legeforen 2015; 135: 132-6.

2. Elverland HH. Spedbarn som ikke hører. Tidsskr Nor Legeforen 2015; 135: 103.

3. Townsend CL, Forsgren M, Ahlfors K et al. Long-term outcomes of congenital cytomegalovirus infection in Sweden and the United Kingdom. Clin Infect Dis 2013; 56: $1232-9$

4. Kadambari S, Williams EJ, Luck $\mathrm{S}$ et al. Evidence based management guidelines for the detection and treatment of congenital CMV. Early Hum Dev 2011; 87 . $723-8$

\section{S-H. Anderssen og medarbeidere svarer:}

Vi takker for en konstruktiv kommentar fra Rollag og medarbeidere til vår artikkel om medfødt hørselstap i Østfold 2000-2009. Det gis her argumenter for at det bør diskuteres om nyfødte med mulig nedsatt hørsel bør screenes for medfødt infeksjon med Cytomegalovirus (CMV).

I vår artikkel er ikke CMV-infeksjon diskutert fordi ingen i materialet hadde påvist CMV-infeksjon. Dette ble imidlertid omtalt i vår artikkel i Tidsskriftet nr 22/2002, fordi én nyfødt prematur hadde CMV-infeksjon i innkjøringsfasen av hørselsscreeningen i 1999, og i tillegg til alvorlig hørselstap også utviklet en alvorlig cerebral parese (1). I dag gjøres diagnostikk av CMVinfeksjon på nyfødtintensivavdelinger kun hvis barnet har symptomer som kan være forenlig med denne infeksjonen.

Ut fra referansene som Rollag anfører vil $0,5 \%$ av nyfødte ha medfødt CMV-infeksjon og 10-20\% av disse utvikle nevrologisk sekvele, oftest i form av hørselstap. I vårt materiale med nærmere 30.000 nyfødte, ville 150 ha medfødt infeksjon og 15-30 ha nevrologisk sekvele. Vi fant totalt 41 barn med hørselstap hvor av 31 ble påvist fra fødsel av og 10 senere. Av disse hadde 13 genetisk disposisjon og flere hadde andre risikofaktorer. Derfor kan det kanskje reises spørsmål om den reelle forekomst av medfødte, CMV-relaterte hørselstap har det omfang som er beskrevet $\mathrm{i}$ litteraturen.

Medfødt hørselstap er hyppigere enn alle andre medfødte sykdommer til sammen som dekkes av nyfødtscreeningen i dag. Siden CMV-infeksjon er en reell risikofaktor med både diagnostikk- og 